\title{
$\mathrm{EV} / \mathrm{HEV}$ 용 모터 구동 시스템의 Noise 예측을 위한 통합 시뮬레이션에 대한 연구
}

\section{Total Simulation for the Noise Prediction of Motor Driving System in $\mathrm{EV} / \mathrm{HEV}$ System}

\author{
권오현 · 이재중 · 김광호 · 안지현 · 권혁수* · 김미로* · 정상용 · 나완수 \\ O-Hyun Gwon · Jae Joong Lee $\cdot \mathrm{Kwang}-\mathrm{Ho} \mathrm{Kim} \cdot \mathrm{Ji}-\mathrm{Hyun}$ Ahn $\cdot$ Hyuck-Su Kweon* \\ Mi-Ro Kim* $\cdot$ Sang-Yong Jung $\cdot$ Wansoo Nah
}

요 약

본 연구에서는 배터리 내부의 회로 모델링, 다이나믹 다이오드를 이용한 인버터, 2-D EM Tool을 이용한 모터 의 해석 결과를 합친 $\mathrm{EV} / \mathrm{HEV}$ 용 모터 구동시스템의 통합 시뮬레이션 방법을 제안한다. 배터리의 모델링을 위해 서 충전상태(DOD: Depth of Discharge)에 따라서 변화하는 인덕턴스, 저항, 캐패시턴스 성분을 $\mathrm{AC}$ 임피던스 분 석법을 이용하여 산출하였으며, 역회복 시간이 반영된 다이나믹 다이오드를 사용하여 인버터를 모델링하였다. 모터의 특성은 매입형 영구 자석 모터의 EM 필드 해석을 Ansys Maxwell 15.0 버전을 사용하여 모델링하였다. 즉, 배터리 및 인버터의 회로 모델과 EM 필드 해석을 통한 모터 해석 모델을 통합한 시뮬레이션 방법을 제시하 고, 전체의 통합 모델링을 Ansys Simplorer 10.0 버전을 사용하여 수행하였다. 그리고 이를 통하여 EV/HEV 모터 구동회로의 전도성 노이즈 스펙트럼 분석을 수행하였고, 그 분석 결과가 정성적으로 유의미함을 확인하였다.

\begin{abstract}
The noise prediction of motor driving system is one of the most important parts in EV/HEV, as the number of power electronic devices increases. This paper describes the mechanism of noise making process and proposes a simulation model of motor driving system for the prediction of the conducted noise. Theoretical calculations and model based simulations were carried out. DOD-dependent-battery parameters were extracted by AC analysis, and an inverter model including dynamic diode was used. Furthermore, 2-D EM tool was used for the motor modeling and was combined with the circuit models of battery and inverter. The simulated voltages, currents and spectrums in the motor driving system showed qualitatively meaningful results, suggesting the validness of the suggested modeling methods.

Key words : MDS(Motor Driving System), Battery Modeling, Co-Simulation, Motor, Bus Bar
\end{abstract}

$$
\text { I. 서 론 최근 전기자동차에 대한 많은 연구와 함께 자동 }
$$

\footnotetext{
「이 연구는 2013년도 산업통상자원부의 재원으로 한국에너지기술평가원(KETEP)의 지원을 받아 수행한 연구 과제(No.2012-0993$000)$ 입니다.」

「이 연구는 2012년도 현대모비스 연구비의의 지원으로 수행한 연구 과제입니다.」

성균관대학교 전자전기컴퓨터공학과(Department of Electronical and Computer Engineering, Sungkyunkwan University)

*(주)현대모비스 기술연구소(Hyundai Mobis Technical Research Center Co., Ltd.)

- Manuscript received June 1, 2013 ; Revised July 3, 2013 ; Accepted July 22, 2013. (ID No. 20130601-06S)

· Corresponding Author : Wansoo Nah (e-mail : wsnah@skku.edu)
} 
차 내에 들어가는 전기제품들이 많아지면서 특히 하 이브리드/전기 자동차와 같이 고전압/고전류를 사용 하는 시스템에서 발생하는 노이즈는 여러 전기 제품 에 영향을 미치고 있다. 이러한 문제는 단순하게는 오디오 불량에서부터, 심하게는 교통사고에 이르는 치명적인 문제까지 야기할 수 있다. 이러한 이유 때 문에 하이브리드/전기 자동차에서의 $\mathrm{EMC}($ Electromagnetic Compatibility) 문제는 이전의 내연기관을 사 용하는 자동차에서보다 훨씬 더 중요하게 부각되고 있고, 현재에도 연구기관 및 연구소들에서 이러한 문제를 해결하기 위해 많은 연구와 노력이 진행되고 있다. 현재 이러한 문제들은 개발하고자 하는 자동 차의 프로토타입을 제작하면서 시행 착오(trial and error) 방법으로 발생된 노이즈 문제를 해결해 나아 가고 있는 실정이다. 이러한 시행착오 방법은 설계/ 제작 후에 $\mathrm{EMC}$ 테스트를 통해서야 수정이 가능하 므로, 시간적인 그리고 물자적인 면에서 많은 문제 를 내포하고 있다. 보다 근본적으로는 설계 단계에 서부터 $\mathrm{EMC}$ 를 고려한 설계가 함께 이루어져야 보 다 효율적으로 많은 $\mathrm{EMC}$ 문제들을 해결할 수 있을 것이다 ${ }^{[1]}$.

모터 구동 시스템(MDS: Motor Driving System)은 기본적으로 배터리-인버터-모터로 연결되는 기본적 인 시스템을 말하며, 자동차 내에 동력을 만드는 메 인 모터(IPMSM 등) 에서부터 와이퍼를 작동시키는 작은 $\mathrm{DC}$ 모터까지 다양하게 사용된다. 지금까지 모 터 구동 시스템에서의 노이즈 예측을 위한 여러 가 지 연구가 발표되어 왔으멸,[3], 최근에는 히트 싱크, 고전압 케이블, 모터의 고주파 파라메터 추출을 바 탕으로 하여 공통모드 노이즈 결합 경로를 분석하고, 그것을 기반으로 한 노이즈 발생을 예측한 논문이 발표된 바 있다 ${ }^{[4]}$. 기본적으로 이러한 기존의 연구에 서는 시스템을 구성하는 각 요소의 기생 파라메터들 을 추출하여, 전체 시스템을 등가 회로화 하여 노이 즈를 예측하여왔다. 하지만, 최근 들어 모터의 크랭 크샤프트(Crankshaft)를 경로로 한 공통 모드 노이즈 가 발견되는 등, 기계적인 경로/역학을 고려한 모터 구동 모델링 시스템의 개발이 필요하지만 ${ }^{[4]}$, 기존의 등가 회로모델링 기법만으로는 기계적인 역학을 고 려한 노이즈 경로를 예측하는 데에 한계가 있다. 본 연구에서는 특히 모터 부분을 등가 회로화 하지 않
고, 모터 내부의 $\mathrm{EM}$ 필드를 해석하여 전체 해석을 수행하였다. 이와 더불어서 배터리의 충전 상태에 따라서 변화하는 배터리의 회로 모델링과 역회복 시 간을 갖는 실제 인버터의 다이나믹 다이오드 모델링 을 수행하였다. 그리고 이와 같이 수행된 회로 해석 과 $\mathrm{EM}$ 필드 해석 부분이 효과적으로 결합된다. 이 와 같은 방법은 모터의 EM 필드 해석을 수행하기 때문에 현실에 더 가까운 모델링을 할 수 있게 되며, 그 결과로 모터의 기계적인 성질(예를 들어서 토크) 까지 연계하여 시뮬레이션할 수 있게 된다는 장점을 가지게 된다. 즉, 기계적인 역학을 고려한 모터 구동 모델링을 개발하고자 할 때, 반드시 필요한 모델링 기법이라는 것을 알 수 있다.

본문 2-1장에서는 시간 영역과 주파수 영역의 특 성을 반영하는 배터리 모델링에 대한 소개를 하고 2-2장에서 인버터의 구성품인 다이나믹 다이오드에 대하여 기술하며, 2-3장에서는 핵심적인 부품 모터 의 FEM 모델이 제시되어 있으며, 3장에서 이 전체 를 통합하는 $\mathrm{Co}$-시뮬레이션 기법과 그 결과가 제시 되어 있다. 최종적으로 결론 부에서 추출된 노이즈 에 대한 분석을 하고자 한다.

\section{II. 모터 구동 시스템 요소의 등가회로}

\section{2-1 배터리 등가회로 모델링}

배터리는 이상적인 전압원과 내부 저항의 연결로 표현할 수 있다미 하지만, 이러한 단순한 모델로는 배터리의 개회로 전압(OCV: Open circuit voltage)에 서 충/방전 특성을 반영하지 못하기 때문에, 배터리 의 충전 상태(SOC: State of Charge)에 따라서 파라메 타가 달라지는 비선형(nonlinear) 모델이 필요하다. 식 (1)은 이러한 비선형 모델의 수식적 표현이다 ${ }^{[7]}$.

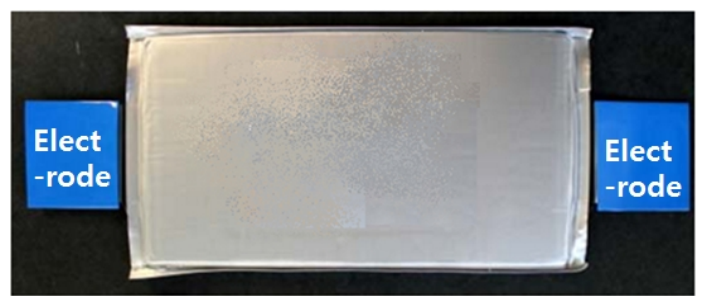

그림 1. $\mathrm{EV} / \mathrm{HEV}$ 모터 구동 시스템의 배터리 셀

Fig. 1. Battery cell for EV/HEV motor-driving-system. 
THE JOURNAL OF KOREAN INSTITUTE OF ELECTROMAGNETIC ENGINEERING AND SCIENCE. vol. 24, no. 7, Jul. 2013.

표 1. 시뮬레이션에 사용된 배터리 셀의 사양

Table 1. Specifications of a battery cell.

\begin{tabular}{|c|c|c|}
\hline Item & Rating & Unit \\
\hline Battery capacity & 5.3 & Ah \\
\hline Cut-off voltage & 2.5 & V \\
\hline Nominal voltage & 3.75 & V \\
\hline Maximum voltage & 4.35 & V \\
\hline Discharging rate & 1 & $\mathrm{C}$ \\
\hline
\end{tabular}

$$
E=E_{0}-k \frac{Q}{Q-\int_{0}^{t} i(\tau) d \tau}+A e^{B \int_{0}^{t} i(\tau) d \tau}-\operatorname{err}(x)
$$

$\operatorname{err}(x)=a_{1} \times e^{-\left(\frac{x-b_{1}}{c_{1}}\right)^{2}}+a_{2} \times e^{-\left(\frac{x-b_{2}}{c_{2}}\right)^{2}}$

$E$ : Open circuit voltage $(\mathrm{V})$

$Q:$ Battery capacity(Ah)

$A$ : Exponential zone amplitude(V)

$B$ : Exponential zone time constant inverse(Ah) ${ }^{-1}$

$k$ : Polarization voltage $(\mathrm{V})$

$E_{0}$ : Battery constant voltage $(\mathrm{V})$

표 2. $\mathrm{OCV}(\mathrm{E})$ 수식에 사용된 파라미터

Table 2. Parameters used in the $\operatorname{OCV}(E)$ formula.

\begin{tabular}{|c|c|c|c|}
\hline Parameter & Value & Parameter & Value \\
\hline$\alpha_{1}$ & 0.3537 & $\alpha_{2}$ & -1.624 \\
\hline$b_{1}$ & 0.7372 & $b_{2}$ & 1.5160 \\
\hline$c_{1}$ & 0.3028 & $c_{2}$ & 0.1073 \\
\hline$Q$ & 5.3 & $Q_{\exp }$ & 1.06 \\
\hline$Q_{\text {nom }}$ & 4.93 & $A$ & 0.2 \\
\hline$B$ & 2.83 & $k$ & 0.0903 \\
\hline
\end{tabular}

본 연구에서 사용된 배터리의 사양과 외관은 표 1 및 그림 1 에 나타나 있으며, 측정된 충/방전 특성은 그림 2의 점선으로 나타나 있다. 식 (1)에서 보이는 여러 상수들은 측정된 충/방전 곡선을 이용하여 구 할 수 있으며, 구한 결과를 표 2에 정리하였다. 아울 러 그림 2의 실선은 표 1의 상수를 식 (1)에 적용하 여 나타낸 것으로 실제 측정된 충/방전 특성을 잘 나 타내고 있음을 알 수 있다.

위에서 기술한 배터리의 충/방전 특성은 느린 시 간의 영역에서의 특성으로, 주파수에 대한 응답 특

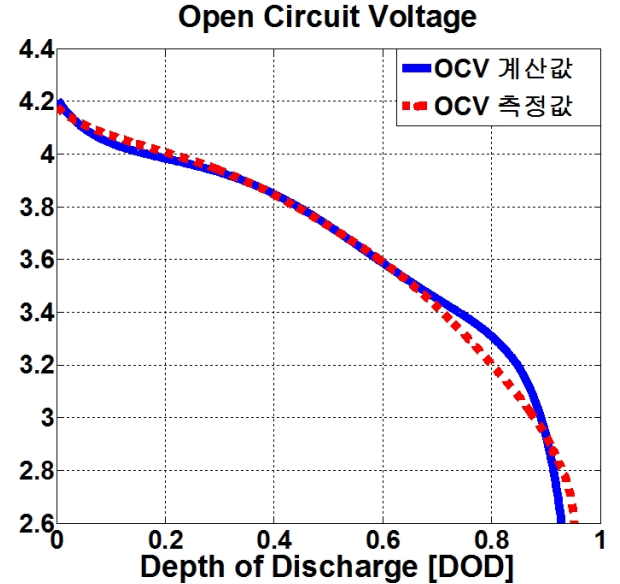

그림 2. 배터리 방전에 따른 개회로 전압

Fig. 2. Open circuit voltages depending on DOD.

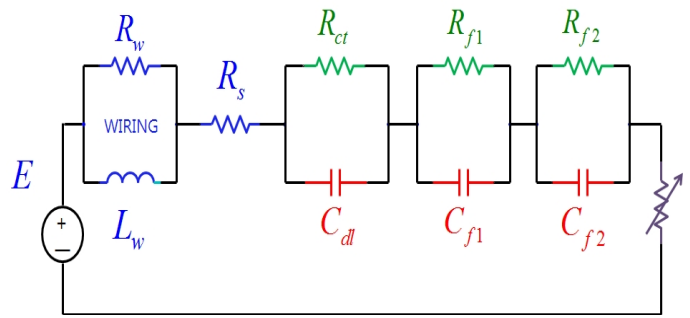

$L_{w}:$ Wire inductance

$R_{s}$ : Solution resistance

$R_{c t}:$ Charge transfer resistance

$C_{d l}:$ Double layer capacitance

$R_{f l}:$ Film 1 resistance

$C_{f 1}:$ Film 1 capacitance

$R_{f 2}:$ Film 2 resistance

$C_{f 2}$ : Film 2 capacitance

그림 3. 가변 저항을 갖는 배터리 등가회로 모델링

Fig. 3. Battery equivalent circuit with varying resistor.

성은 고려가 되어 있지 않다. 이는 배터리의 충/방전 시험이 충분히 느린 시간에서 측정이 되기 때문이 며, 따라서 $\mathrm{AC}$ 특성을 고려하기 위해서 그림 3 과 같 은 회로소자가 추가로 요구된다. 이렇게 추가된 회 로 소자들은 배터리의 물리적 특성에서부터 정의되 어 사용되어지며, 자세한 설명은 아래와 같다.

일반적으로 배터리의 등가회로 모델링 방식은 전 하 전달 저항 $\left(R_{c t}\right.$ : charge transfer resistance)과 커패시 터 $\left(C_{d l}\right.$ : double layer capacitance), 분리 막 용해 저항 $\left(R_{s}\right.$ : solution resistance), 분리 막 사이 표면 저항 $\left(R_{f}\right.$. 
surface films resistance)과 커패시터 $\left(C_{f}\right.$ : surface films capacitance)의 병렬 연결로 모델링해왔다 ${ }^{[8]}$. 하지만 배터리 등가회로의 관심주파수가 높아지면서 배터 리에 연결되는 양극 단자의 인덕턴스 성분 $\left(L_{w}\right.$ : wire inductance)과 저항 성분 $\left(R_{w}\right.$ : wire resistance)도 무시할 수 없게 되었으며, 그림 3에서는 이 성분들이 원주 모양과 같이 포함되어 있다. 그리고 이 등가회로에 서의 $L-R-C$ 성분들은 배터리의 $\mathrm{AC}$ 임피던스를 측정 하고 이를 분석함으로써 그 값들은 구할 수 있다 ${ }^{[9]}$.

모터 구동 시스템에서는 주된 노이즈 원이 IGBT 인버터의 스위칭에 발생되므로, $0.01 \mathrm{~Hz}$ 부터 스위칭 주파수인 $10 \mathrm{kHz}$ 까지의 임피던스를 나이키스트 플 롯으로 나타내었다 ${ }^{[10]}$. 측정은 배터리 방전이 $10 \%$ 인 곳마다 측정하였고, 측정 결과는 나이키스트 형 태로 그림 4 에 제시되어 있다. 이는, 주파수가 올라 감에 따라 허수부가 양의 부호를 띄게 되며, 이는 인 덕턴스 성분이 커지게 된다는 것을 의미한다. 따 라서, 바로 앞에서 언급한대로 배터리의 인덕턴스 성분과 저항을 무시할 수 없다는 것을 보여주고 있다.

$$
\begin{aligned}
D O D=x & \\
L_{\text {wire }}(x)= & \left(8.145 x^{5} \times 10^{-1}+2.627 x^{4}\right. \\
& +2.716 x^{3}-1.085 x^{2}+1.562 x \\
& \left.\times 10^{-1}+1.991\right) \times 10^{-7} \\
R_{\text {wire }}(x)= & -1.401 x^{5}+3.608 x^{4}-3.204 x^{3} \\
& +1.163 x^{2}-0.1556 x+0.08634 \\
R_{s}(x)=- & 0.001075 x^{5}+0.00468 x^{4} \\
- & 0.005433 x^{3}+0.002541 x^{2} \\
- & 0.0005797 x+0.00187 \\
C_{f 1}(x)= & -652.8 x^{5}+1801 x^{4}-1537 x^{3} \\
& +489.5 x^{2}-77.62 x+47.44 \\
C_{f 2}(x)= & -14.01 x^{5}+42.72 x^{4}-43.13 x^{3} \\
& +17.89 x^{2}-3.292 x+2.253 \\
R_{c t}(x)= & 0.4329 x^{5}-0.8399 x^{4}+0.5064 x^{3} \\
& -0.0662 x^{2}-0.0246 x+0.00591 \\
R_{f 1}(x)= & 0.02022 x^{5}-0.02656 x^{4}+0.0085 \\
R_{f 2}(x)= & -0.02015 x^{5}+0.05969 x^{4} \\
& -0.05612 x^{3}+0.02104 x^{2} \\
& -0.002596 x+0.0005946
\end{aligned}
$$

측정된 임피던스를 바탕으로 그림 3에서 충/방전 상태에 의존하는 $L-R-C$ 성분들을 추출할 수 있다. 추 출은 EChem Software Zsimpwin Tool을 사용하였고,
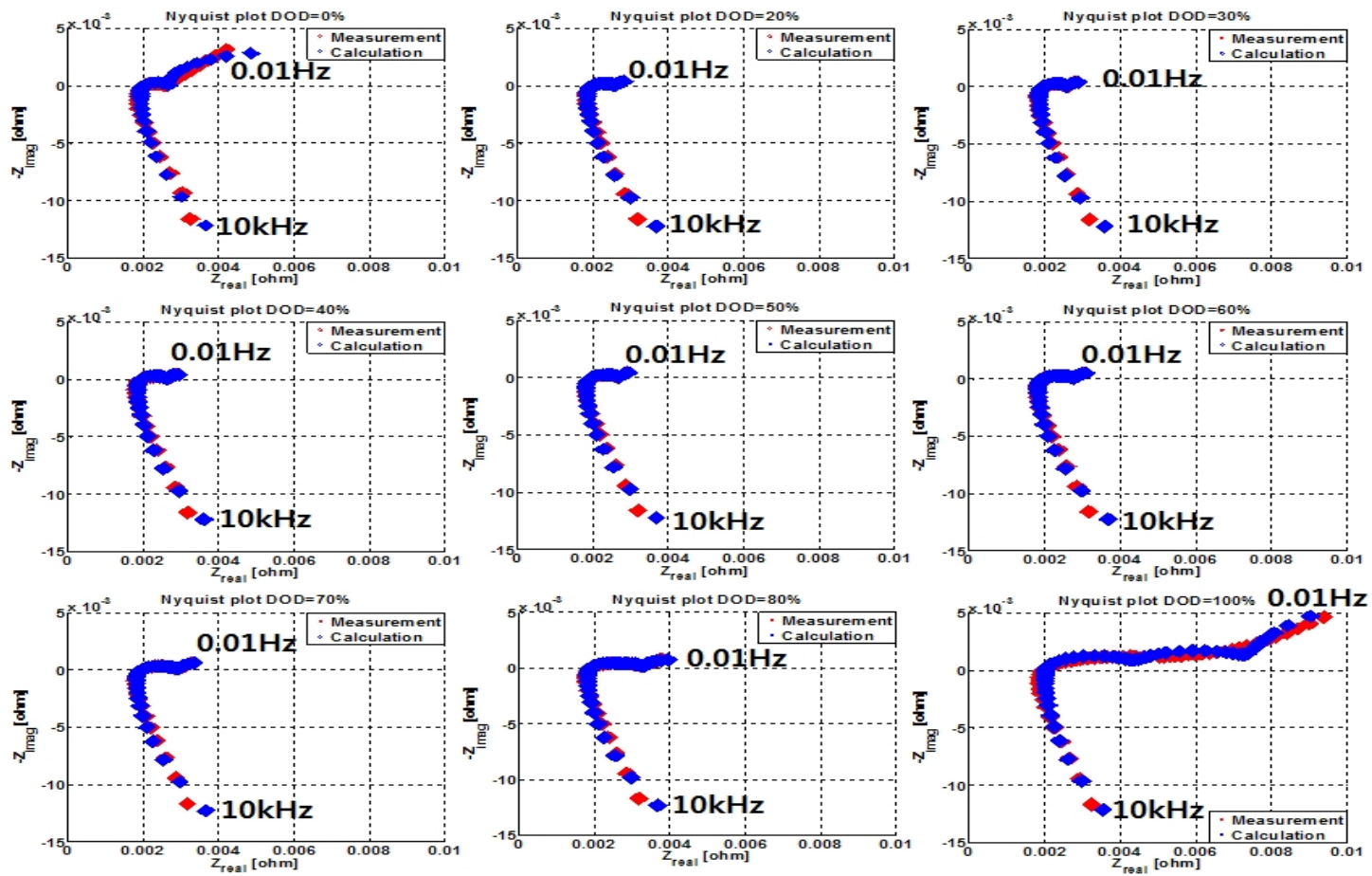

그림 4. 방전 상태에 따른 임피던스의 나이퀴스트 플롯

Fig. 4. Nyquitst plot of impedance versus DOD. 

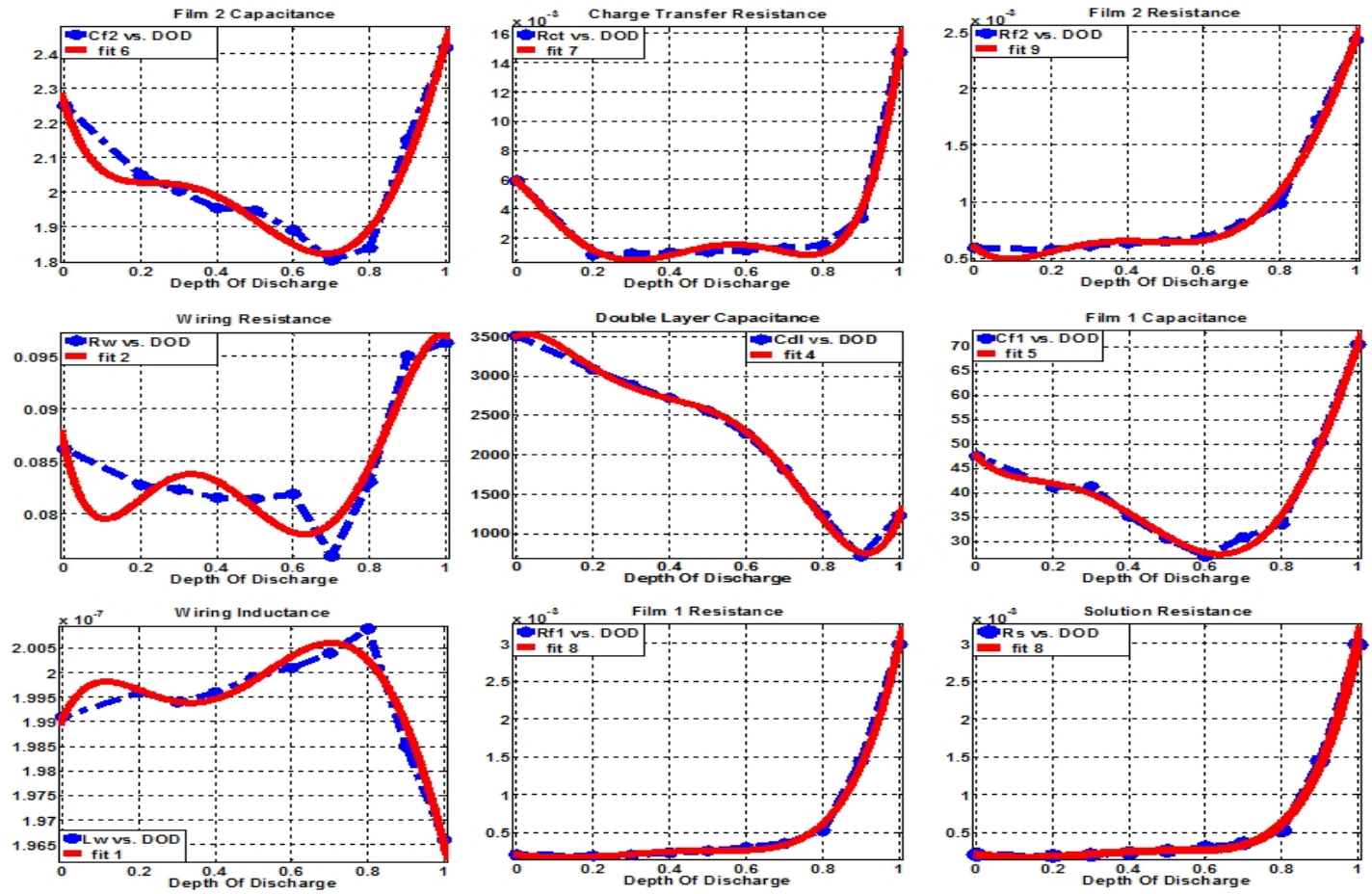

그림 5. 방전 상태에 따른 배터리 파라메터 측정 및 결과

Fig. 5. Battery parameter measurement and result versus DOD.

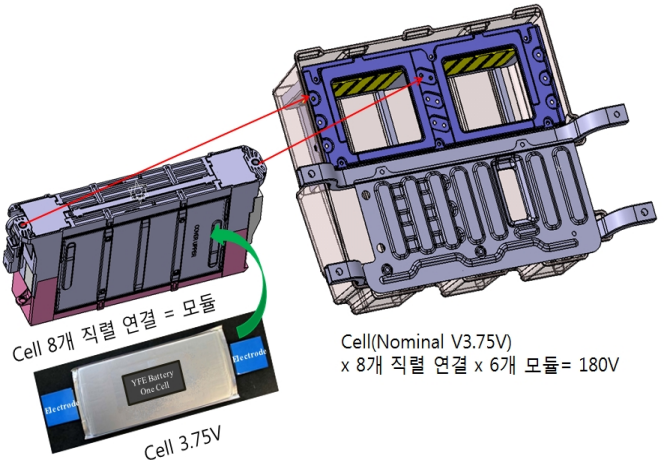

그림 6. 전형적인 배터리 셀의 모습

Fig. 6. Typical battery module and one cell.

추출된 결과를 토대로 5 차 함수로 피팅하였다. 곡선 피팅시 사용한 식은 식 (2)와 같은 뉴턴 재차분 보간 다항식(Newton divide difference interpolation polynominal equation)을 이용하였고, 곡선 피팅에 따른 $L$ $R-C$ 결과가 실험값과 일치함을 그림 5 를 통해 확인 할 수 있다.

이렇게 방전상태에 따른 저항, 커패시턴스 그리고 인덕턴스의 값을 수식으로 구함으로써, 지금까지 배

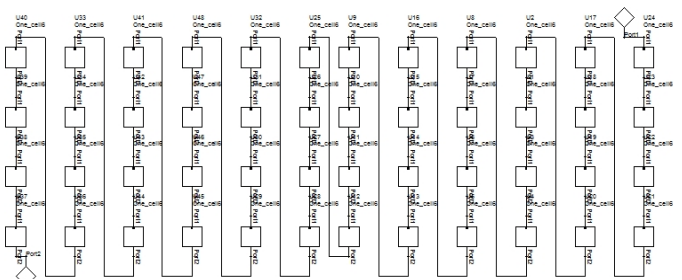

그림 7. 48셀-배터리 팩 모델링

Fig. 7. Modeling battery pack of 48 cells.

터리 하나의 셀을 모델링을 하였지만, 실제 모터 구 동 시스템에서는 그림 6 과 같이 8 개의 셀이 하나의 모듈을 이루고, 6 개의 모듈이 하나의 배터리 팩을 이루는 구조이다. 이러한 실제 모델을 반영하기 위 해 위에서 모델링한 배터리를 그림 7과 같이 48 셀 로 연결하였으며, 실제 모터 구동 시스템에서 반영 하였다.

앞에서 분석한 배터리 한 개의 셀을 48셀에 반영 하게 될 때, 대략적인 전류 및 전압의 감소함을 알 수 있는데, 예를 들어 그림 4를 통해서 일반적인 인 버터의 스위칭 주파수인 $10 \mathrm{kHz}$ 에서 배터리 내부 임 


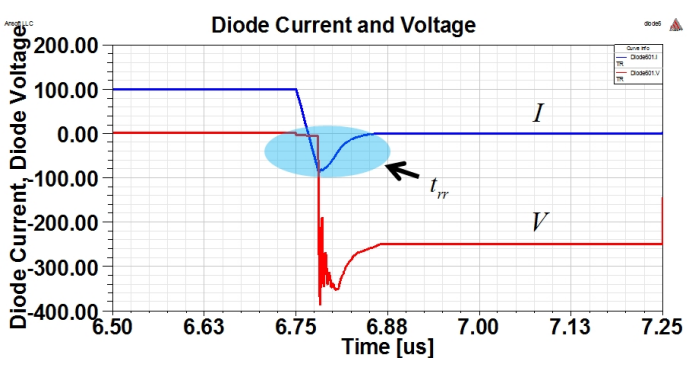

그림 8. 다이나믹 다이오드의 역회복 전류 및 시간

Fig. 8. Reverse recovery current and time in dynamic diode.

피던스는 $0.0121 \Omega$ 이고, 48셀의 경우에는 $0.0121 \Omega$ $\times 48=0.5808 \Omega$ 정도이며, $10 \mathrm{kHz}$ 에서 $1 \mathrm{~A}$ 의 전류가 흐른다면, 배터리 단에서만 $0.5805 \mathrm{~V}$ 만큼의 전압 변 동이 예상된다. 이러한 분석은 전체 주파수 영역에 서 모두 해석이 되어져야 하며, 따라서 배터리 내부 임피던스에 기인한 배터리 단에서 전압 변동은 그 양이 매우 클 것으로 예상되며, 또 이것은 배터리로 구동되는 시스템의 경우 배터리의 정확한 모델링이 매우 중요하다는 것을 말해준다.

\section{2-2 인버터부의 다이오드 등가회로 모델링}

인버터는 $\mathrm{DC}$ 를 $\mathrm{AC}$ 로 변환해 주는 소자(그림 12 참조)이며, $\mathrm{EV} \_\mathrm{HEV}$ 용 모터구동 시스템에서 인버터 를 구현하기 위해서는 순방향 전압 저지와 양방향 전류 특성을 가져야 한다. 이러한 이유로 스위칭 소 자와 다이오드를 조합하여 사용하고 있으며, 스위칭 소자로는 온/오프가 쉬운 IGBT가 많이 이용되고 있 다. 이상적인 다이오드는 순방향 바이어스(forward bias)시 온되고, 역방향 바이어스(reverse bias)시 오프 되는 소자이다. 하지만, 실제 인버터에 사용되는 다 이나믹 다이오드(dynamic diode)는 그림 8과 같이 순 방향 바이어스에서 역방향 바이어스로 전환될 때, 역방향으로 역회복 시간(reverse recovery time) $t_{r r}$ 동 안 전류가 흐르게 된다 ${ }^{[11]}$. 본 논문에서는 인버터 회 로에 역회복 시간을 고려하여 진행하였고, 또 실제 다이나믹 다이오드에 존재하는 접합 캐패시턴스(junction capacitance), 확산 퍼텐셜(diffusion potential) 등 등의 파라미터를 반영하였다. 그리고 인버터는 공간 벡터 PWM 제어방식(SVPWM: Space Vector Pulse Width Modulation)을 사용하였다.

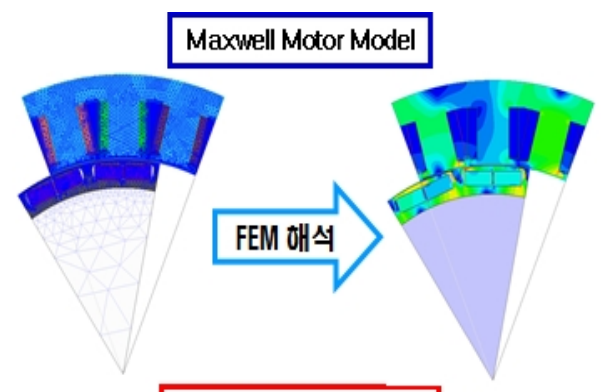

Simplorer Motor Model

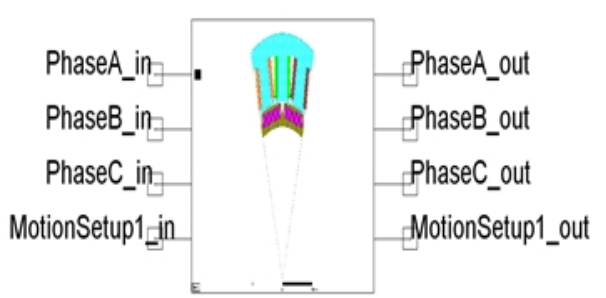

그림 9. 모터의 FEM 해석 모델(윗 그림) 및 통합 모 델에서의 모터부(아래 그림)

Fig. 9. FEM model of a motor(top), and a motor in the total system(bottom).

\section{2-3 모터부의 FEM 모델}

$\mathrm{EV} / \mathrm{HEV}$ 용 모터 구동 시스템에서 사용되는 모터 는 동일한 크기 및 무게에 대비하여 큰 자속을 일정 하게 유지할 수 있고, 출력이 큰 영구자석 동기 전동 기가 많이 사용되고 있다. 더 세부적으로는 매입형 영구자석 동기전동기(IPMSM: Interior Permanent Magnet Synchronous Motor)를 많이 사용하고 있는데, 그 이유는 표면 부착형 영구자석 동기 전동기(SPMSM: Surface Permanent Magnet Synchronous Motor)와 비교 하여 매입형의 경우가 고속주행시 안정도가 더 높기 때문이다. 매입형 영구자석 동기전동기는 영구자석 에서 발생된 자속과, 고정자의 코일 사이에서 발생 하는 합성자속의 각도를 최대토크가 발생하는 조건 으로 구동시킨다 ${ }^{[12]}$.

매입형 영구자석 동기전동기의 FEM 모델과 통합 시뮬레이션에 적용된 모터모델을 그림 9에 나타내 었다. 즉, $\mathrm{FEM}$ 방식으로 모터의 $\mathrm{EM}$ 필드를 해석할 때의 장점 중의 하나는 모터의 형상 및 재질의 변한 후 통합 모델에서 각 상의 정보를 주고 받게 된다. 이에 따라 모터 모델과 여기에 연결되는 회로모델 사이에 적절한 정보를 주고받는 연결의 흐름도를 그 


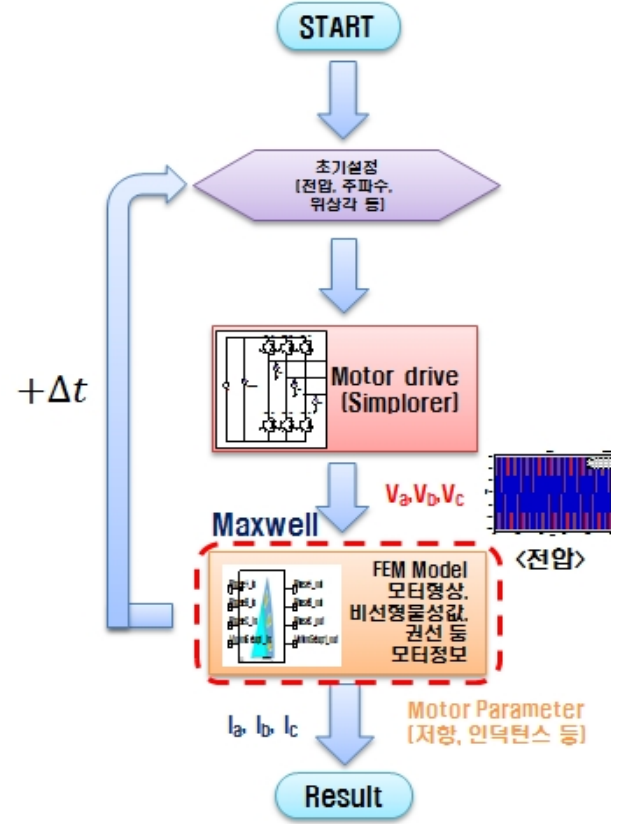

그림 10. FEM 모델과 회로 모델링 사이의 연결 흐름도

Fig. 10. Connection flow chart between FEM and circuit models.

림 10에 나타내었다. 그림 10 에 나타나 있듯이, 초기 에 기 설정된 배터리의 전압과 인버터의 스위칭 주 파수, 모터의 동작주파수와 최대 토크가 발생하는 기계각에 따른 전기각의 위상을 설정하고, 배터리를 통해 인버터를 지나 출력되는 Open 상태에서의 3상 출력 전압정보를 연결된 2-D FEM 모터 모델에 전달 하고, 전달된 정보는 모터의 $\mathrm{rpm}$ (revolution per minute)에서 해당하는 저항과 인덕턴스로 계산되는 임 피던스 정보와 계산되어 전류가 계산되어 출력되는 순서로 이루어진다. 그리고 미소 시간이 지난 후에 변화된 파라메터 값을 토대로 계산이 다시 진행되 며, 궁극적으로 해석하고자 하는 시간까지 반복적으 로 이루어진다. 이와 같이 미소시간 동안 모터의 회 전에 의해서 변화하는 형상을 고려하여 해석이 진행 되기 때문에 전체 시스템을 해석하기 위해서는 고성 능의 컴퓨터와 많은 계산 시간을 필요로 한다. 본 연 구에서는 CPU I5-3550를 기준으로 전체 계산시간이 80 90시간 정도 소요되었다. 모터 드라이브 시스템 에서 모터를 $\mathrm{FEM}$ 으로 해석화가 전체 모터 드라이브 시스템에 미치는 영향을 분석할 수 있는 기반을 제 공해 준다는 것이다. 그러한 하나의 예를 그림 10

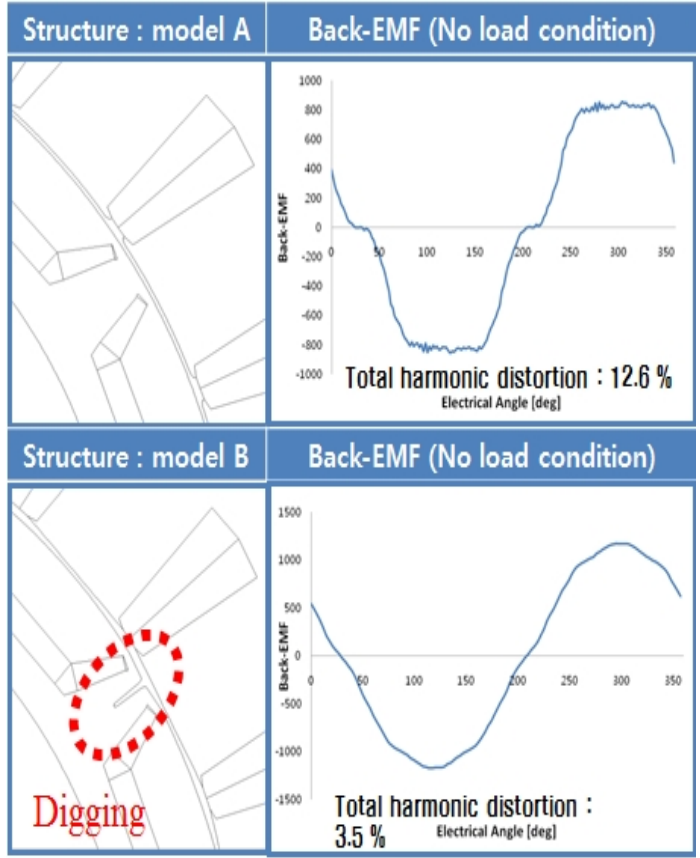

그림 11. 전고조파 왜곡율을 줄이기 위한 모터의 설계 Fig. 11. Motor design to reduce torque ripple.

이 보여준다. 즉, 매입형 영구자석 모터는 구조상 회 전자 내부에 영구자석이 있기 때문에, d축과 $q$ 축 간 의 자기저항(reluctance)이 다르며, 이런 자기저항의 차이에 의해 발생하는 토크의 요동을 줄이기 위해 그림 11 과 같이 공극의 길이가 증가하는 방향으로 홈을 파서 자기저항의 차이를 줄일 수 있도록 설계 하였다. 그 결과, 역기전력의 전고조파 왜율(THD: Total Hamonic Distortion)이 그림 11의 아래와 같이 감 소하였음을 보여 주고 있다.

\section{Co-Simulation}

모터 구동 시스템의 통합 시뮬레이션을 그림 12 에 나타내었으며, 배터리와 인버터, 인버터와 모터 사이에 대 전류를 흐르게 하는 부스바를 연결하였 다. 인버터는 제어부에 의해서 제어되는데, 제어는 공간 벡터 PWM 방식으로 제어되며, 시뮬레이션의 샘플링 주기는 50 us, 설정된 샘플링 주기에 맞게 타 임 스텝은 1.25 us로 설정하였고, 높아진 인버터의 주파수를 반영하기 위해 스위칭 주파수는 $10 \mathrm{kHz}$ 로 설정하였다. 또, 인버터의 목적이 모터를 제어하기 


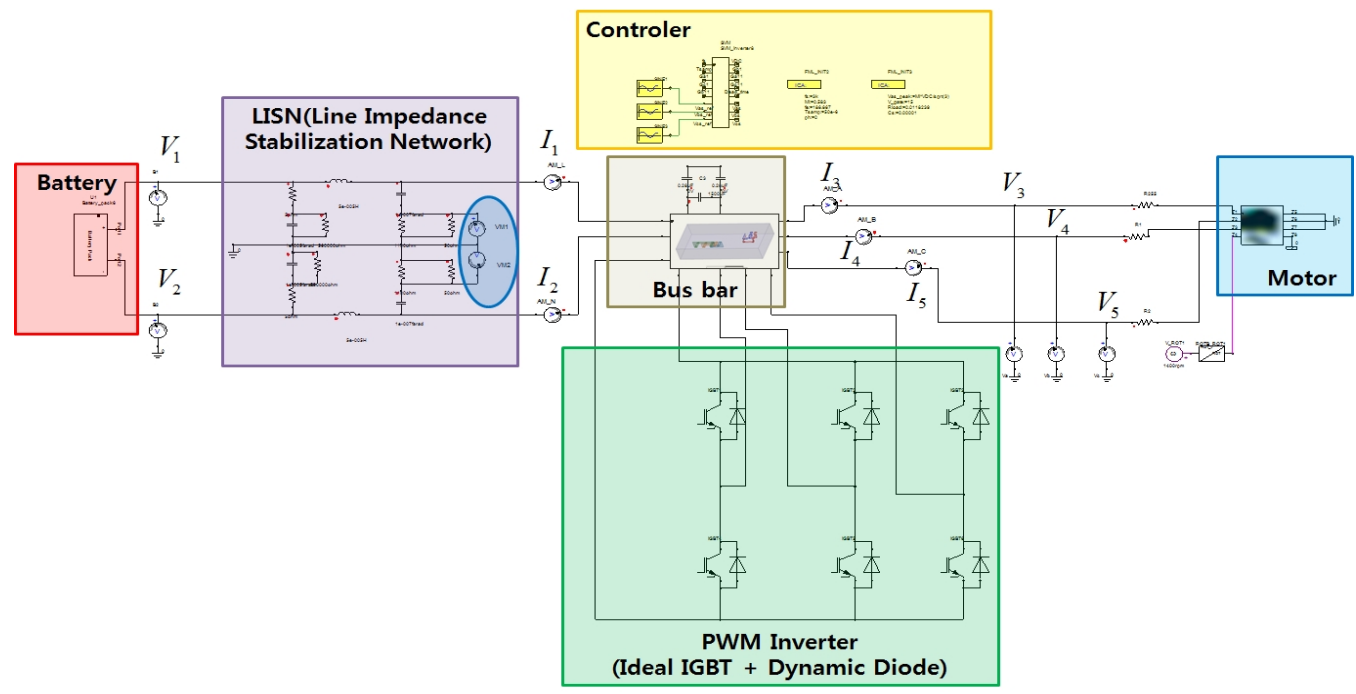

그림 12. 모터 구동 시스템의 전체 회로도

Fig. 12. Total circuit of a motor driving system in EV/HEV.

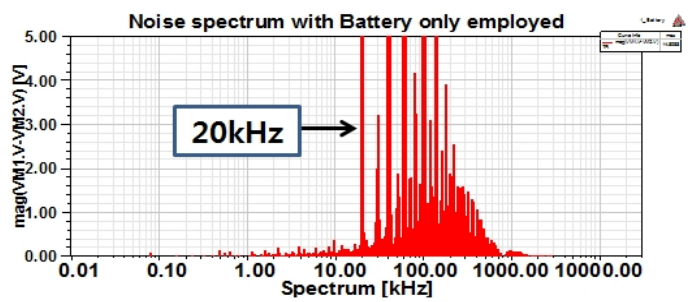

(a) 배터리 모델만이 적용된 경우

(a) Only employed battery

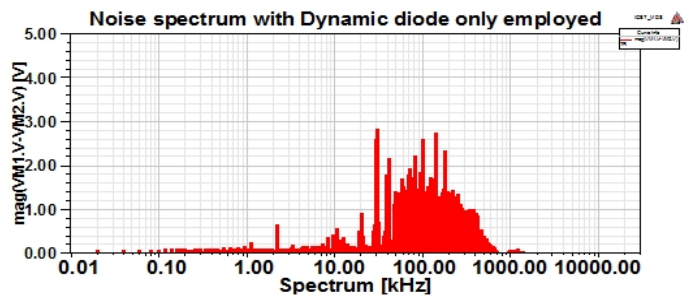

(b) 다이나믹 다이오드 모델만이 적용된 경우

(b) Only employed dynamic diode

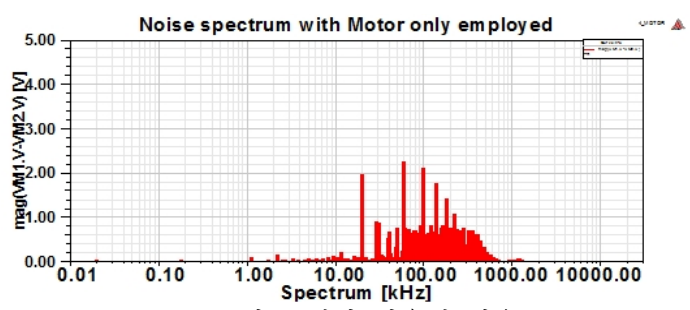

(c) 모터 모델만 적용된 경우

(c) Only employed motor

그림 13. LISN에서 관찰된 노이즈

Fig. 13. Noise spectrum at LISN.
위함이므로, 모터의 $\mathrm{rpm}$ 과 극수로 계산된 동작주파 수 $186.667 \mathrm{~Hz}$, 제어 변조지수는 0.583 을 반영하였다. 모터의 회전속도는 $1,400 \mathrm{rpm}$ 으로 설정하였다. 각각 의 시스템들에서 발생시키는 노이즈를 살펴보기 위 하여, 모델링된 개별 시스템에 대한 전도성 방사를 시뮬레이션 하였다. 실제 실험 시에 전도성 방사 측 정을 위해서는 LISN(Line Impedance Stabilization Network)을 이용하며, 이 상황을 반영하기 위하여 그림 12에서와 같이 LISN 회로를 삽입하였으며, 시뮬레 이션 결과에서 계산된 노이즈는 이 LISN 회로에서 검출된 노이즈를 의미한다.

그림 13은 여러 가지 경우에서 LISN에서 관찰된 노이즈를 보이고 있다. 첫 번째 스펙트럼은 다른 모 든 소자를 이상적으로 놓고 배터리 모델만을 적용한 결과이며, 두 번째 스펙트럼은 다른 모든 소자를 이 상적으로 놓고 역전류가 고려된 다이나믹 다이오드 모델만을 적용한 경우, 그리고 마지막 스펙트럼은 다른 모든 소자를 이상적으로 놓고 모터의 모델만을 고려하여 적용한 결과다. 이러한 분석은 각 소자(배 터리, 다이나믹 다이오드, 그리고 모터) 중에서 전압 의 변동(전도 노이즈)에 가장 크게 미치는 소자를 분 석하기 위함이고, 그림에서 볼 수 있듯이 배터리만 을 고려할 때 가장 노이즈가 크다는 것을 알 수 있으 며, 이 결과는 2-1절에서 배터리의 내부 임피던스에 


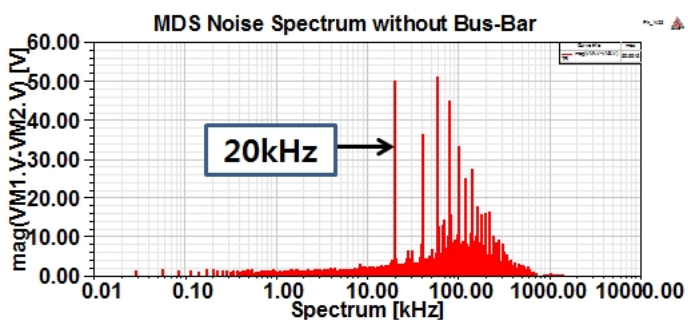

(a) 부스바가 없을 때

(a) Without bus bar

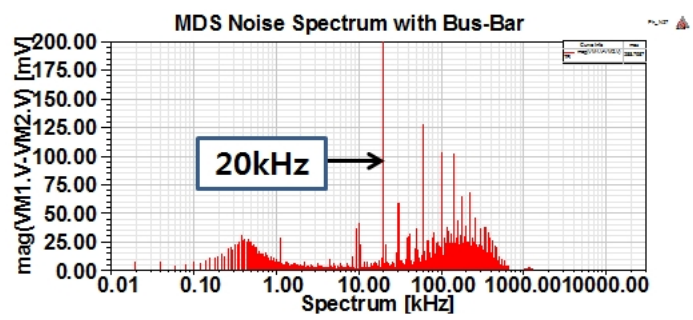

(b) 부스바가 있을 때

(b) With bus bar

그림 14. 모터 구동 시스템의 노이즈 스펙트럼

Fig. 14. Noise spectrum in motor driving system.

의한 배터리 단자 전압의 변동이 매우 클 수 있다는 분석 결과와 일치한다. 그리고 전반적으로 $20 \sim 700$ $\mathrm{kHz}$ 사이에서 공통적으로 노이즈가 발생하고 있으 며, 특히 배터리의 경우에는 $20 \mathrm{kHz}$ 에서 $15 \mathrm{~V}$ 로 강 하게 나타나는 것을 확인하였다. 인버터는 스위칭 주파수 $10 \mathrm{kHz}$ 내에서 인버터가 3상 대칭 변조 방식 에 맞춰 제어되고 있다. 이것은 $10 \mathrm{kHz}$ 내에서 두 번 의 스위칭이 일어난다는 의미이므로, 실질적인 주기 는 전체의 절반이 되고, 그에 따른 주파수도 $20 \mathrm{kHz}$ 가 되게 된다. 또, 그림 14 는 배터리와 인버터, 그리 고 모터 전체를 고려하였을 때의 시뮬레이션 결과이 다. 특히 아랫쪽 그림은 배터리와 인버터 사이, 그리 고 인버터와 모터 사이에 Bus bar 모델을 삽입하였 을 때의 노이즈 분석 결과이며, 위쪽의 그림은 이러 한 부스 바 모델을 사용하지 않았을 때의 결과이다. 이 두 경우의 노이즈 스펙트럼을 비교하면, 부스 바 모델을 삽입하였을 때 노이즈가 크게 감소하였음(50 $\mathrm{V} \rightarrow 288 \mathrm{mV}$ )을 볼 수 있다. 이는 Bus bar 시스템이 필터링 효과를 낼 수 있다는 것을 의미하며, 이 측면 에서 기존의 연구 결과와 일치한다 ${ }^{[13]}$.

마지막으로 그림 15 에서 전체 통합 시뮬레이션을
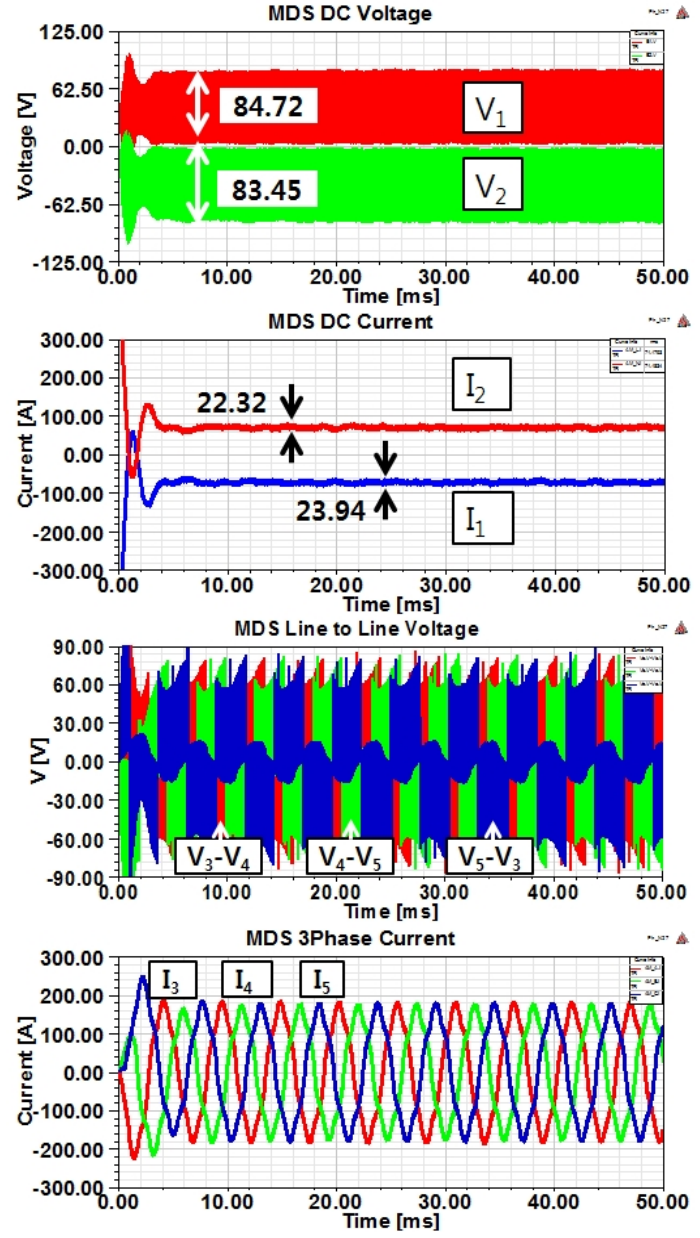

그림 15. 모델링이 반영된 모터 구동 시스템의 전압 과 전류

Fig. 15. Simulated voltages and currents in motor driving system.

통한 $\mathrm{DC}$ 전류와 전압, 3 상전류와 전압을 나타내었 다. $\mathrm{DC}$ 전압은 그림 12 의 $V_{1}, V_{2}$ 에서, $\mathrm{DC}$ 전류는 그 림 12 의 $I_{1}, I_{2}$ 에서, 선간 전압은 그림 12 의 $V_{3}-V_{4}, V_{4}$ $-V_{5}, V_{5}-V_{3}$ 에서, 3 상 전류는 그림 12 의 $I_{3}, I_{4}, I_{5}$ 에서 각각 관찰된 것이다. 2-1절에서 언급한대로 $\mathrm{DOD}$ 가 0 에서의 한 개의 셀에 대한 OCV는 $4.2 \mathrm{~V}$ 이고, 배터 리 한 팩은 48셀로 구성되어 있기 때문에 $4.2 \mathrm{~V} \times 48=$ $201 \mathrm{~V}$ 가 나온다. 하지만, 그림 15 의 첫 번째 그림과 같이 실제 $\mathrm{DC}$ 전압은 $V_{1}$ 과 $V_{2}$ 의 차인 $84.72+83.45$ $=168 \mathrm{~V}$ 로 배터리 내부의 임피던스에 $33 \mathrm{~V}$ 전압 강하 가 이뤄졌음을 알 수 있다. 이에 따른 결과로 배터리 내부 임피던스에 의해서 $\mathrm{DC}$ 전압이 감소할 수 있음 


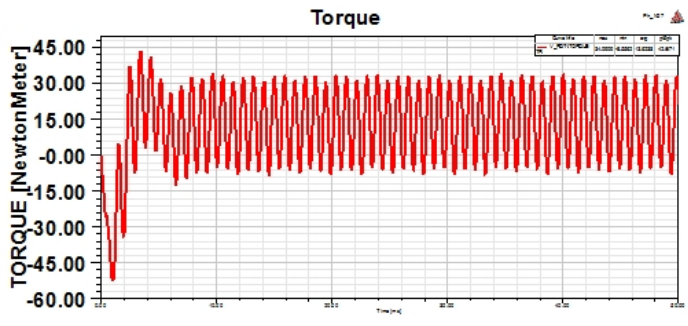

그림 16. 모터의 토크

Fig. 16. Torque of a motor.

을 예측할 수 있다. 또, 그림 15 의 세 번째 그림의 선 간 전압들이 영전압 기준에서 전압이 영전압이 아닌 양극, 음극으로 벗어나 있는 것을 확인할 수 있는데, 이는 역 회복 시간을 갖는 다이나믹 다이오드와 부 스 바의 영향으로 볼 수 있다. 마지막으로 그림 15 의 네 번째 그림을 보면, DC 전류를 받아 인버터에서 스위칭된 결과로 3 상 전류의 상이 올바르게 나오는 것으로써 인버터의 스위칭이 잘 이뤼졌으며, 이를 통해 시뮬레이션이 정성적으로 유의미하게 해석 되었다는 것을 알 수 있다.

그림 16에서는 필드 해석을 통해서만 확인할 수 있는 통합 시뮬레이션에서의 모터의 토크를 관찰할 수 있다. DC 전류와 전압, 3 상 전류와 전압이 초기 영역에서는 과도 상태이다가, 시간이 지난 후 정상 상태에 도달하였음을 관찰할 수 있다. 이에 대한 결 과로 토크 역시 과도 상태에서, 3 상 전류와 전압이 정상상태로 진입하였을 때 맞춰 정상 상태가 되는 것을 보임으로써, 2-D FEM 모델과 회로 모델 간의 연결로 인해 $\mathrm{EM}$ 필드 해석을 수행하였고, 이 결과 로 토크를 관찰할 수 있다는 장점을 보였다.

\section{$\mathrm{IV}$. 결 론}

본 논문에서 제안한 하이브리드/전기 자동차 노 이즈 예측을 위한 통합 시뮬레이션은 배터리, 인버 터의 회로 모델과 모터의 필드 해석을 통하여, 전도 노이즈를 예측할 수 있음을 보였다. 특히 모터는 $\mathrm{EM}$ 필드 해석을 이용하여 모델링을 수행하였고, 모터 이전 단에 있는 인버터 및 배터리는 등가회로 모델 링을 통하여 접근하였으며, 두 모델링을 통합하여 전체 시스템이 해석될 수 있음을 보였다. 본 해석을 통하여 전도성 노이즈의 근본적인 원인이 인버터의
스위칭 노이즈에 있으며, 제어 방식에 따라서 노이 즈의 메인 주파수가 변할 수 있다는 것을 보여주었 으며, 또한, 회로적 모델링과 필드 해석을 하는 FEM 모델을 연계시킨 통합시뮬레이션을 통해서만 얻을 수 있는 모터의 토크 데이터를 산출하였다. 인버터 스위칭에 기인한 노이즈는 모터 드라이브의 각 부분 회로에 영향을 미치지만, 특히 배터리의 내부회로에 서 큰 영향을 미친다는 것을 알 수 있었으며, 이는 배터리 모델링의 중요성을 말해준다.

본 논문에서는 배터리의 등가회로 및 모터의 해 석을 $\mathrm{EM}$ 시뮬레이션을 통하여 구현하였으며, 많은 계산 시간(80 90시간, I5-3550 기준) 후에, 정성적으 로 유의미한 결과를 얻을 수 있다는 것을 확인하였 다. 본 논문을 바탕으로 배터리와 인버터의 회로 모 델과 모터의 기계적 해석(예를 들어서 열 해석)을 연 동을 하는데 기반이 될 것으로 판단되며, 추후에 컴 퓨터의 성능 향상과 더불어 보다 실제에 가까운 $\mathrm{EM}$ 모델링이 가능할 것으로 보이며, 이와 더불어 좀 더 빠르고, 더 정확한 예측을 할 수 있을 것으로 기대 된다.

\section{References}

[1] 육종관, 나완수, "PCB 및 IC 회로에서의 EMC 기 술 연구 동향", 한국전자파학회지 전자파기술, 23 (4), pp. 32- 42, 2012년 7월.

[2] Jih-Sheng Lai, Xudong Huang, Elton Papa, Shaotang Chen, and Thomas W. Nehl, "Inverter EMI modeling and simulation methodologies", IEEE Transactions on Industrial Electronics, vol. 53, no. 3, pp. 736-744, Jun. 2006.

[3] Gary Skibinski, Rangarajan Tallam, Robert Reese, Brian Buchholz, and Richard Lukaszewski, "Common mode and differential mode analysis of three phase cables for PWM AC drives", IEEE Industry Applications Conference, Tampa, FL, pp. 880-888, Oct. 2006.

[4] 정기범, 이종경, 정연춘, 최재훈, "전기자동차 모 터 구동 시스템의 전도 방출에 관한 고주파 모델 링 연구", 한국전자파학회논문지, 24(1), pp. 8290, 2013년 1월. 
[5] 김병기, 이병국, 나완수, "하이브리드 자동차 모 터 구동 시스템의 전도/방사 노이즈에 관한 연구 동향", 한국전자파학회지 전자파기술, 21(3), pp. 16-25, 2010년 5월.

[6] James Larminie, John Lowry, Electric Vehicle Technology Explained, $2^{\text {nd }}$ Edition, John Wiley \& Sons, pp. 29-32, 2012.

[7] 이재중, 이준상, 김미로, 권혁수, 나완수, "하이브 리드 자동차 배터리의 고주파 해석 모델링", 전 기학회논문지, 61(2), pp. 263-269, 2012년 2월.

[8] June-Sang Lee, Jae-Joong Lee, Byung-Ki Kim, JungGu Kim, Ki-Sik Lee, and Wanspp Nah, "Electric model of Li-ion polymer battery for motor driving circuit in hybrid electric vehicle", Journal of Electrical Engineering \& Technology, vol. 7, no. 6, pp. 932-939, Nov. 2012.

[9] Toshiyuki Momma, Mariko Matsunaga, Daikichi Mukoyama, and Tetsuya Osaka, "AC impedance analysis of lithium ion battery under temperature con-
권 오 현

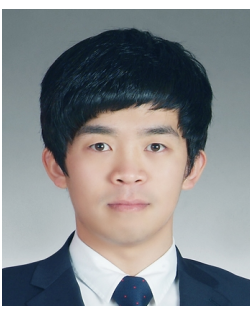

2012년 2월: 수원대학교 전자공학 과 (공학사)

2012년 3월 현재: 성균관대학교 전 자전기컴퓨터공학과 석사과정 [주 관심분야] $\mathrm{EMI} / \mathrm{EMC}$ in Vehicle, Multiconductor Analysis
이 재 중

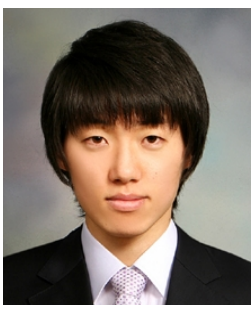

2010년 2월: 동국대학교 반도체과 학과 (공학사)

2012년 2월: 성균관대학교 전자전 기컴퓨터공학과 (공학석사)

[주 관심분야] $\mathrm{EMI} / \mathrm{EMC}$ in Vehicle trol", Journal of Power Sources, vol. 216, pp. 304307, Oct. 2012.

[10] Tetsuya Osaka, Toshiyuki Momma, Daikichi Mukoyama, and Hiroki Nara, "Proposal of novel equivalent circuit for electrochemical impedance analysis of commercially available lithium ion battery", Journal of Power Sources, vol. 205, pp. 483486, May 2012. Robbins, Power Electronics, $3^{\text {rd }}$ Edition, John Wiley \& Sons, pp. 17, 538-539, 2003.

[12] 원충연, "그린카 인버터 기술의 이해와 현황", 한티미디어, pp. 97-121, 2012년.

[13] Jae-Joong Lee, Wansoo Nah, "Influence of bus bar parasitic effects on motor driving system with battery circuit model", IEEE Vehicle Power and Propulsion Conference, Seoul, Korea, pp. 1033-1036, Oct. 2012.
[11] Ned Mohan, Tore M. Undelang, and William P.
김 광 호

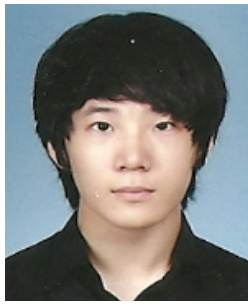

2013년 2월: 성균관대학교 전자전기 컴퓨터공학과 (공학사) 2013년 2월 현재: 성균관대학교 전 자전기컴퓨터공학과 석사과정 [주 관심분야] $\mathrm{EMC/EMI}$

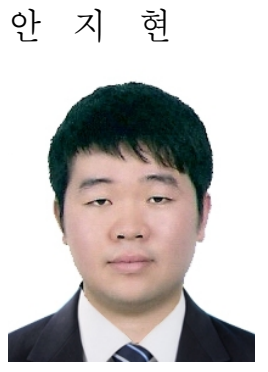

2012년 2월: 동아대학교 전기공학 과 (공학사)

2012년 3월 현재: 성균관대학교 전 자전기컴퓨터공학과 석사과정 [주 관심분야] 최적화, 모터설계 
$\mathrm{EV} / \mathrm{HEV}$ 용 모터 구동 시스템의 Noise 예측을 위한 통합 시뮬레이션에 대한 연구

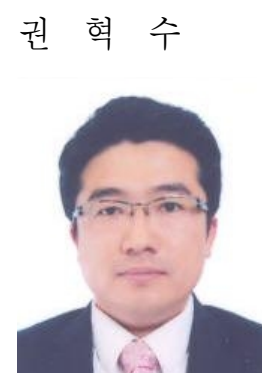

팀 근무
2002년 2월: 건국대학교 물리학 과 (이학사)

2004년 2월: 건국대학교 물리학 과 (이학석사)

2004년 2004년: 삼성 ENG

2005년 2006년: CMS

2006년 현재: 현대모비스 공학해석

[주 관심분야] $\mathrm{EMI} / \mathrm{EMC}$ in Vehicle
정 상 용

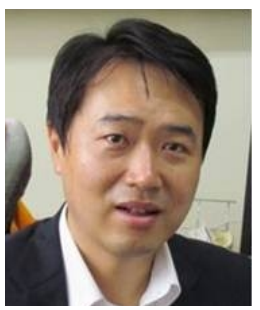

1997년 2월: 서울대학교 전기공학 과 (공학사)

1999년 2월: 서울대학교 전기공학 과 (공학석사)

2003년 2월: 서울대학교 전기공학 과 (공학박사)

2003년 2006년: 현대기아자동차 연

구개발본부 선임연구원

2006년 2011년: 동아대학교 조교수

2011년 현재: 성균관대학교 전자전기컴퓨터공학과 부교수

[주 관심분야] 최적화, 모터설계

나 완 수

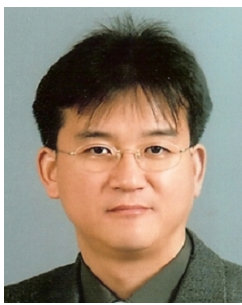

1984년 2월: 서울대학교 전기공학 과 (공학사)

1986년 2월: 서울대학교 전기공학 과 (공학석사)

1991년 2월: 서울대학교 전기공학 과 (공학박사)

1991년 1993년: SSCL Guest Collaborator

1993년 1995년: 한국전기연구원 선임연구원

1995년 현재: 성균관대학교 전자전기컴퓨터공학과 교수 [주 관심분야] SI, PI, EMI/EMC 